\title{
$\mathrm{AMI}$ 기반 원격 펌웨어업그레이드 시스템 개발을 위한 요구분석 및 설계에 관한 연구

\section{A Study on the Requirements Analysis and Design for System Development of Remote Firmware Upgrade Management System Based-on AMI}

\author{
정 남 준 ${ }^{*}$ 양 일 권**최 승 환*·진 영 택**
}

(Nam-Joon Jung $\cdot$ Il-Kwon Yang $\cdot$ Seong-Hwan Choi $\cdot$ Young-Taek Jin)

\begin{abstract}
The firmware upgrade, which is remotely performed, is an essential function in smart metering or AMI (Advanced Metering Infrastructure). In other words, the AMI software and firmware can be switched for maintaining and improvement without replacement of $\mathrm{H} / \mathrm{W}$ devices in AMI environment. Also, if number and type of devices are increase, the demand of remote update service will be increased. Through the firmware upgrade service remotely, the electric power corporation may be able to benefit various fields. For example, there are to adapt more easily in many environments, real-time service and to cut maintenance costs. In this paper, we proposed to design an international level FUMS(Firmware Upgrade Management System) which includes requirement function, architecture and protocol related with DCU, Smart Meter.
\end{abstract}

Key Words : AMI, Smart meter, DCU, Firmware upgrade

\section{1. 서 론}

수용가의 전력사용량 취득을 위한 원격 검침은 산업용 고 압 고객의 경우는 약 14 만의 고객에 대하여 $\mathrm{CDMA}$ 통신을 이용하여 운영 중이며, 저압 고객의 경우는 2010 년까지 약 55 만의 고객을 대상으로 PLC 기반의 통신 방식으로 운영 중이다.[1] 정부와 한전 계획에 의하면 향후 저압고객 1,800 만 고객에 대하여 2020년까지 원격검침 시스템을 구축하여 운영예정이므로 관리해야할 미터 및 관련 장비의 수량은 상 당한 규모가 될 것이다.[2] 유틸리티 입장에서 본다면 이러 한 장비들의 관리 및 유지 보수를 위한 비용 및 방법들이 고려되어야 하며, 그리고 무엇보다도 즉각적인 서비스 변경 을 요할 경우는 시간적인 제약이 관리에 어려움을 줄 수도 있을 것이다. 현재 운영중인 $\operatorname{AMR}$ (Automatic Meter Reading) 시스템은 미터에 대한 장애 혹은 폄웨어 프로그램 변경시 대상 미터를 교환하거나 혹은 $\mathrm{PDA}$ 혹은 $\mathrm{PC}$ 와 같은 미터 원격 접속 가능 기기를 통하여 미터가 있는 근접 지역 에서 제어 프로그램을 변경하거나 환경 등을 설정할 수 있 는 체계를 가지고 있다. 이러한 인력에 의한 근접 지원 체 계는 향후 $\mathrm{AMI}$ 환경에서는 비효율적이며 꼭 개선되어야 할 부분이다.

또한 위와 같은 기술 요구에 따라 국제적으로도 미국 국 립기술표준원인 NIST(National Institute of Standards and

† 교신저자, 정회원 : 한국전력공사 전력연구원

E-mail : njjung@kepco.co.kr

* 정 회 원 : 한국전력공사 전력연구원

** 비 회 원 : 한밭대학교

접수일자 : 2011년 9월 23일

최종완료 : 2011년 11월 22일
Technology)는 미터 업그레이드 표준의 중요성을 인식하여 미터 업그레이드 표준을 스마트그리드 구현을 위한 우선 표 준화 계획인 $\mathrm{PAP}$ (Priority Action Plan)의 결과물로 선정하 여, 2009년에 NEMA(National Electrical Manufacturers Association) 주관의 '미터 업그레이드' 표준을 제정하였 다.[3][4] 본 논문에서는 'NEMA에서 제정한 미터 업그레이 드 표준 요구 기능을 기반으로 국내에서 적용하기 위한 $\mathrm{AMI}$ 기반의 미터 및 $\mathrm{DCU}(\mathrm{Data}$ Collection Unit)의 원격 펌 웨어 업그레이드를 위한 요구 기능 도출 및 시스템 개발을 위한 설계 결과를 제시하고자 한다.

\section{2. 관련연구}

\subsection{AMI와 펌웨어 업그레이드시스템}

최종 전력 소비자와 전력회사 사이의 전력서비스인프라인 $\mathrm{AMI}$ 는 양방향 전력정보 교환을 요구하는 지능형 전력망 (Smart Grid) 구현에 필수적인 핵심 인프라 시스템이며, 공 급자와 공급자간 상호 인지 기반 수요반응(Demand Response) 실현을 위한 기본 인프라이다. 그리고 수용가의 부하 자원 데이터에 대한 실시간 전송 및 이러한 자료의 $\mathrm{DB}$ 화를 통하여 다양한 부가서비스를 구축할 수 있을 것으 로 기대되는 시스템이다.[5] 또한 향후 예상되는 다양한 유 형의 분산전원체계, 배전지능화시스템 등과 정보 연계 등 미 래 지능형 전력망 운용을 위해 요구되는 최우선 지능화 전 력망 인프라 시스템으로서 중요성이 크다고 할 수 있다. $\mathrm{AMI}$ 는 그림 1 과 같이 스마트미터와 $\mathrm{IHD}, \mathrm{PCT}$ 그리고 Smart Appliances을 포함하는 홈네트웍 서비스 영역과 $\mathrm{DCU}$ 와 $\mathrm{ADCS}$ 로 구성된 데이터 수집영역, $\mathrm{MDMS}$ (Mater Data Management System), MDW(Meter data Warehouse) 로 구성된 미터데이터 관리 영역, 다양한 연계시스템과 응용 
서비스로 구성된 서비스 영역 그리고 $\mathrm{NOC}$ (Network Operation Center)와 같은 네트웍 관리 영역으로 구성된 다.[6][7]

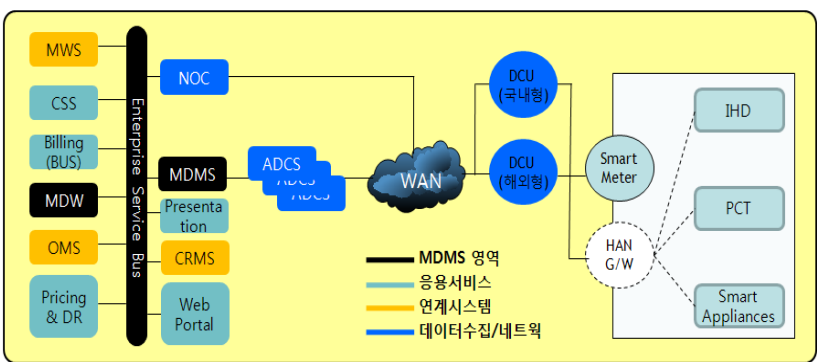

그림 $1 \mathrm{AMI}$ 시스템 구성도

Fig. 1 Architecture of AMI system

원격검침 사업의 특징 중 하나는 대규모 사업의 형태로 진 행되는 것을 들 수 있다. 이로 인해 단말의 설치 후 소프트 웨어 및 펌웨어 등의 수정이 필요시 전국 규모로 설치됨에 따라 운영에 많은 인력의 투입과 혼선이 예상된다. 이러한 문제점을 해결하기 위해 원격 펌웨어 업데이트 방법 등이 최근 데이터 전송장치에 적용되고 있으며, 이를 토대로 수용 가에 신규 서비스 등을 지원하기 용이해 졌다. 초기 AMR 시스템에서는 전력사용량만을 원격에서 읽어오는 기능만을 수행하였으나, AMI 시스템으로 진화함에 따라 100여 가지 의 OBIS Code를 기반으로 검침 데이터를 취득하고 더 나아 가 변압기 감시, 고객 전력정보 및 부가서비스 등을 제공함 으로서 데이터 전송장치 및 전력량계와 같은 현장 단말의 구성은 더욱 복잡 해 지고 있다. 특히 현장에 설치되어 무 인 환경에서 운영이 되는 시스템 특성상 이를 효과적으로 유지보수 하는 것이 AMI 시스템 운영의 핵심이다. 위와 같 은 문제를 해결할 수 있는 기술로는 단말내에 존재하는 하 드웨어를 제외한 모든 데이터를 원격에서 접근하여 효율적 으로 제어 및 관리하는 기술인 $\mathrm{DM}$ (Device Management)이 존재한다. $\mathrm{DM}$ 기술을 $\mathrm{AMI}$ 시스템에 적용할 경우 전력회사 가 단말을 관리하고 응용서비스를 시작, 개선, 관리하는 과 정의 가이드 라인을 제공 할 수 있다.[8]

\section{2 스마트미터 업그레이드를 위한 요구사항 표준}

NIST의 요청으로 개발된 NEMA의 스마트미터 업그레이 드 요구사항은 스마트 미터(이하 $\mathrm{SM}$ ), 방법론, $\mathrm{AMI}$ 프로그 램 및 통신, HAN(Home Area Network) 프로그램 및 통신, 업그레이드 관리 시스템과 같은 기능적 요구사항과 보안 요 구사항을 기술하고 있다.[4]

\subsubsection{Smart Meter}

1) 스마트 미터는 NMS(Network Management System) 및 업그레이드 관리 시스템으로부터 정의된 쿼리에 따라 각 구성요소의 펌웨어 현재 버전을 확인해야 한다.

2) 만약 업그레이드를 완료 하지 못했을 때, SM는 NMS 및 업그레이드 관리 시스템의 "Failed Upgrade Process" 경 고로 이전 펌웨어로 복구할 수 있다.
3) $\mathrm{SM}$ 는 업그레이드 효과 전 펌웨어 이미지 접수 완료 를 확인하여야한다.

4) $\mathrm{SM}$ 는 업그레이드 효과 전 펌웨어 이미지 무 결성 검 토의 통과를 확인하여야한다.

5) $\mathrm{SM}$ 업그레이드 프로세스 시도 및 결과는 기록되어야 한다.

6) $\mathrm{SM}$ 펌웨어 업그레이드 후 계량체계 재조정을 필요로 하지 않는다.

7) $\mathrm{SM}$ 펌웨어 업그레이드 후 기존의 구성을 유지하도록 지원한다.

8) 펌웨어 이미지 업데이트를 수신하는 동안 $\mathrm{SM}$ 는 측정 과 측정된 데이터 저장을 계속한다.

9) $\mathrm{SM}$ 는 펌웨어 이미지 업데이트 조정 활성화를 위한 메커니즘을 지원한다.

10) SM 업그레이드 프로세스는 공식적인 시작을 요구한 다.

11) SM는 펌웨어 이미지는 신뢰할 수 있는 원본의 출처 를 확인하여야한다.

\subsection{2 계량체계}

1) 계량체계는 펌웨어 이미지 업그레이드 후 측정된 데 이터가 유지되도록 지원한다.

2) 계량체계는 펌웨어 이미지 업그레이드 후에 재조정이 필요 없다.

3) 계량체계 서브 컴포넌트가 측정 기능과 축적/ 저장 기능으로 나뉘어져 있으며, 측정 기능은 업그레이드가 필요 없다.

\subsubsection{AMI/HAN 프로그램 및 통신}

$\mathrm{AMI}$ 프로그램/HAN 프로그램은 펌웨어 이미지 업그레 이드 후 네트워크 구성을 유지하도록 지원한다.

\section{1 .4 업그레이드 관리시스템}

1) 업그레이드 관리 시스템은 펌웨어 이미지 업데이트 활성화를 위한 메커니즘을 지원한다.

2) 업그레이드 관리 시스템은 업그레이드 프로세스를 완 료하지 못하면 이전에 설치된 펌웨어 이미지로 복원하는 방 법을 지원한다.

3) 업그레이드 관리 시스템 업그레이드 프로세스를 시도 하고 결과를 기록한다.

\section{1 .5 업그레이드 관련 보안 요구사항}

1) 암호화 알고리즘은 현재, 공개적으로 검증되어야 하 며 정부의 승인이 필요하다.

2) $\mathrm{AMI}$ 시스템 설계는 하나의 $\mathrm{SM}$ 가 대형 $\mathrm{AMI}$ 시스템 의 손상을 입히지 않는 것을 보장해야 된다.

3) 보안 보호는 강력한 인증과 무결성 메커니즘을 제공 한다.

4) 보안 보호는 특히 관심을 가진 스위치 분리 및 장치 펌웨어 이미지 수정과 관련해 $\mathrm{SM}$ 내 모든 현장 운영 명령 으로 확대 된다.

5) 보안 보호는 유틸리티의 운영 요구 사항과 고객의 개 인적인 요구사항을 지원한다. $\mathrm{SM}$ 외 보안 보호 요구 사항 
을 위해 제외, 교체 또는 제거되지 않는다.

6) 보안 보호는 SM 데이터의 위조에 대한 보호 기능을 제공한다.

7) AMI 시스템은 HAN내 Smart Grid 통신 네트워크의 심층적인 방어 전략으로 사용된다.

8) $\mathrm{AMI}$ 의 시스템은 $\mathrm{SM}$ 가 손상되거나 비정상적인 활동 이 감지 되었을 때 예외 및 침입 탐지 등을 지원한다.

9) 로깅 및 감사 메커니즘은 인증 또는 암호화된 통신이 실패하면 표시하여야한다.

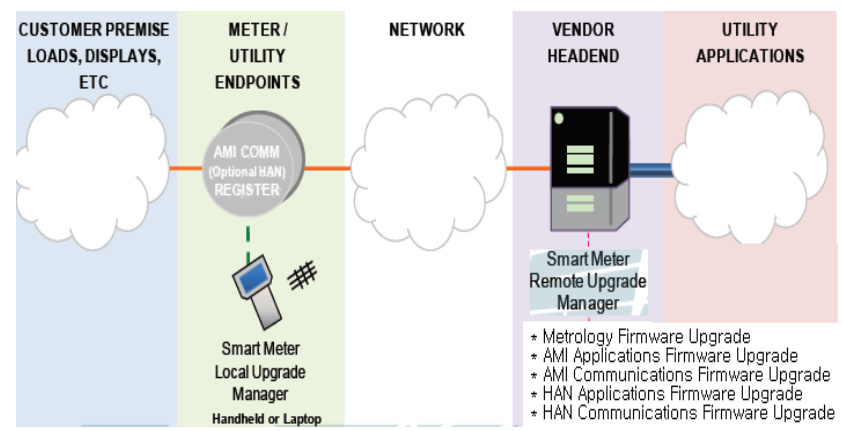

그림 2 원격 펌웨어 업그레이드 체계

Fig. 2 Scheme of remote firmware upgrade

\section{3. 유스케이스 개발 및 시스템 설계}

\section{1 펌웨어 업그레이드 시스템을 위한 유스케이스 개발}

위의 일반적인 원격 펌웨어 업그레이드 시스템의 표준 요 구 기능을 시스템으로 구현하기 위해서는 유스케이스(Use Case)의 개발 과정이 필요하다. $\mathrm{AMI}$ 시스템 관련 장치의 $\mathrm{F} / \mathrm{W}$ 업그레이드기능은 요구기능 추가, 기능 최적화 및 $\mathrm{S} / \mathrm{W}$ 결함 수정 등을 위해 필요하며, 다음과 같은 신규 $\mathrm{F} / \mathrm{W}$ 전송, 신규 $\mathrm{F} / \mathrm{W}$ 업로드, $\mathrm{F} / \mathrm{W}$ 업로드 확인, 신규 $\mathrm{F} / \mathrm{W}$ 전개, 자체 점검 수행 단계로 진행된다.[9]

\subsection{1 일반사항}

\begin{tabular}{|l|l|}
\hline $\begin{array}{l}\text { 사전 } \\
\text { 조건 }\end{array}$ & 현재 $\mathrm{F} / \mathrm{W}$ 버전이 구식, 불완전 또는 부정확 \\
\hline $\begin{array}{l}\text { 사후 } \\
\text { 조건 }\end{array}$ & 신규 $\mathrm{F} / \mathrm{W}$ 버전이 성공적으로 설치 또는 폐기 \\
\hline 변수 & 신규 $\mathrm{F} / \mathrm{W}$ 버전의 설치 날짜 및 시간, 신규 $\mathrm{F} / \mathrm{W}$ 버전 \\
\hline \multirow{2}{*}{ 가정 } & $\begin{array}{l}\mathrm{F} / \mathrm{W} \text { 업그레이드 동안 검침 데이터에 영향이 없어야 함 } \\
\mathrm{F} / \mathrm{W} \text { 업그레이드 동안 디바이스 상태에 영향이 없어야함 } \\
\\
\mathrm{F} / \mathrm{W} \text { 업그레이드 동안 검침 기능에 영향이 없어야 함 }\end{array}$ \\
\hline
\end{tabular}

\subsection{2 유스케이스 - 신규 F/W 전송}

\begin{tabular}{|l|l|}
\hline 기능 & $\begin{array}{l}\mathrm{F} / \mathrm{W} \text { 제공 벤더가 각 버전에 대한 문서(사양서)를 } \\
\text { 제공 }\end{array}$ \\
\hline \multirow{3}{*}{ 이유 } & $\begin{array}{l}- \text { 신규 } \mathrm{F} / \mathrm{W} \text { 로의 업그레이드는 많은 수의 장치에 } \\
\text { 영향을 미칠 수 있어, 결함이 있는 } \mathrm{F} / \mathrm{W} \text { 는 } \mathrm{AMI} \\
\text { 시스템에 부정적인 영향을 미치고 있음 }\end{array}$ \\
\hline
\end{tabular}

\begin{tabular}{|l|l|}
\hline & $\begin{array}{l}\text { 신규 } \mathrm{F} / \mathrm{W} \text { 전송 시 최소한 다음의 정보를 } \\
\text { 제공해야 함 }\end{array}$ \\
적격 & - 이전 버전과 비교시 변경된 사항의 목록(신규 \\
기준 & 기능, 특정 문제에 대한 해결방안) \\
& - 신규 $\mathrm{F} / \mathrm{W}$ 와 호환되는 장치 유형 목록과 이전 \\
$\mathrm{F} / \mathrm{W}$ 버전이 필요한 장치 유형 목록
\end{tabular}

\subsection{3 유스케이스 - 신규 F/W 업로드}

\begin{tabular}{|l|l|}
\hline 기능 & $\begin{array}{l}\text { 미터 등의 디바이스가 신규 } \mathrm{F} / \mathrm{W} \text { 를 업로드 할 수 } \\
\text { 있는 기능을 제공 }\end{array}$ \\
\hline 이유 & $\begin{array}{l}-\mathrm{F} / \mathrm{W} \text { 업그레이드는 기능추가, 기능최적화, } \mathrm{S} / \mathrm{W} \\
\text { 결함 수정 등을 위해 여러 번 수행 가능 }\end{array}$ \\
\hline $\begin{array}{l}\text { 적격 } \\
\text { 기준 }\end{array}$ & $\begin{array}{l}- \text { 신규 } \mathrm{F} / \mathrm{W} \text { 번전이 디 디바이스에 저장 } \\
\text { 통해 확인 가능 }\end{array}$ \\
\hline
\end{tabular}

\subsection{4 유스케이스 - 신규 F/W 전개(설치)}

\begin{tabular}{|l|l|}
\hline 기능 & $\begin{array}{l}1 \text { ) 신규 } \mathrm{F} / \mathrm{W} \text { 업그레이드의 성공이 검침 떼이튼 운영 변수의 수정 또는 삭제 없이 시 } \\
\text { 스템 전반적으로 설치 }\end{array}$ \\
\hline 이유 & $\begin{array}{l}- \text { 신규 } \mathrm{F} / \mathrm{W} \text { 설치 후 디바이스가 정확히 } \\
\text { 작동하며 어떠한 추가적인 조치도 필요하지 않음 }\end{array}$ \\
\hline $\begin{array}{l}\text { 적격 } \\
\text { 기준 }\end{array}$ & $\begin{array}{l}- \text { 미터 등의 작동에 있어 운영적인 변화는 } \\
\text { 없으며 단지 신규 } \mathrm{F} / \mathrm{W} \text { 설치로 인한 } \\
\text { 샹서)만 변경 }\end{array}$ \\
\hline
\end{tabular}

\begin{tabular}{|l|l|}
\hline 기능 & 2) 디바이스가 신규 $\mathrm{F} / \mathrm{W}$ 설치 이벤트를 기록함 \\
\hline 이유 & $\begin{array}{l}- \text { 시스템 유지보수 차원에서 신규 } \mathrm{F} / \mathrm{W} \text { 가 설치 } \\
\text { 또는 폐기된 날짜 및 시간을 알아야 함 }\end{array}$ \\
\hline 적격 & $\begin{array}{l}\mathrm{F} / \mathrm{W} \text { 설치 관련 이벤트 로그 정보는 최소한 } \\
\text { 다음의 정보를 포함해야 함 } \\
- \text { 신규 } \mathrm{F} / \mathrm{W} \text { 버전이 설치되는 타임스탬프 }\end{array}$ \\
\hline
\end{tabular}

3.1.5 유스케이스 - 신규 $\mathrm{F} / \mathrm{W}$ 업그레이드 확인

\begin{tabular}{|l|l|}
\hline 기능 & $\begin{array}{l}1 \text { ) 신규 } \mathrm{F} / \mathrm{W} \text { 가 불완전 또는 일치되지 않는 경우 } \\
\text { 어가 있음을 알림 }\end{array}$ \\
\hline 이유 & $\begin{array}{l}-\mathrm{AMI} \text { 시스템 운영 측면에서 큰 영향을 미칠 수 } \\
\text { 있기 때문에 } \mathrm{F} / \mathrm{W} \text { 업그레이드 실패에 대해서는 } \\
\text { 즉각적으로 에러를 알려야 함 }\end{array}$ \\
\hline 적격 & $\begin{array}{l}- \text { 불완전 또는 일치되지 않는 경우 에러는 } \\
\text { 기준 }\end{array}$ \\
$\begin{array}{l}\text { 일반적인 에러 속성 값을 포함해야 함 } \\
- \text { 에러가 있는 경우 신규 } \mathrm{F} / \mathrm{W} \text { 는 설치되지 않음 }\end{array}$ \\
\hline
\end{tabular}

\begin{tabular}{|c|l|}
\hline 기능 & $\begin{array}{l}2 \text { 2) 신규 } \mathrm{F} / \mathrm{W} \text { 의 확인 작업이 성공적으로 수행되 } \\
\text { 었음을 기록(로그) }\end{array}$ \\
\hline 이유 & $\begin{array}{l}- \text { 시스템 유지보수 차원에서 디바이스가 신규 } \\
\mathrm{F} / \mathrm{W} \text { 를 수신했는지 여부와 } \mathrm{F} / \mathrm{W} \text { 확인이 이루어진 } \\
\text { 날짜 및 시간을 확인해야 함 }\end{array}$ \\
\hline 적격 & $\begin{array}{l}\mathrm{F} / \mathrm{W} \text { 업그레이드 관련 이벤트 로그 정보는 } \\
\text { 최소한 다음의 정보를 포함해야 함 } \\
- \text { 신규 } \mathrm{F} / \mathrm{W} \text { 버전이 확인된 타임스탬프 }\end{array}$ \\
\hline
\end{tabular}




\subsection{6 유스케이스 - 자체 점검 수행}

\begin{tabular}{|l|l|}
\hline 기능 & 디바이스가 자체 점검 기능을 수행 \\
\hline 이유 & $\begin{array}{l}- \text { 신규 } \mathrm{F} / \mathrm{W} \text { 설치 이후 바로 자체 점검이 수행 } \\
-\mathrm{F} / \mathrm{W} \text { 업그레이드 관련 최종 점검 }\end{array}$ \\
\hline $\begin{array}{l}\text { 적격 } \\
\text { 기준 }\end{array}$ & \begin{tabular}{l} 
자체 점음 준숨의 경우 일반적인 담 바이스의 자체 \\
\hline
\end{tabular}
\end{tabular}

\subsection{7 유스케이스 - 신규 F/W 폐기}

\begin{tabular}{|l|l|}
\hline 기능 & 불완전 또는 일치하지 않는 경우 $\mathrm{F} / \mathrm{W}$ 폐기 \\
\hline \multirow{3}{*}{ 이유 } & $\begin{array}{l}\text { 디바이스가 최소어안 } 2 \text { 개의 함(설치된 및 설치예정) } \\
- \text { 신규 } \mathrm{F} / \mathrm{W} \text { 버전을 저 정항할힐 작동하지 않는 경우 } \\
\text { 폐기되며 이전(설치된) 버전 하에서 작동해야 함 }\end{array}$ \\
\hline $\begin{array}{l}\text { 적격 } \\
\text { 기준 }\end{array}$ & $\begin{array}{l}\text { 신규 } \mathrm{F} / \mathrm{W} \text { 버전이 디바이스에 의해 활성화되지 } \\
\text { 임 }\end{array}$ \\
\hline
\end{tabular}

\section{2 펌웨어 업그레이드 시스템 설계}

\subsection{1 시스템 아키텍쳐 설계}

펌웨어 업그레이드 시스템 설계에서 가장 중점을 두어야 할 부분은 시스템 기능의 신뢰도와 많은 자원을 효율적으로 관리할 수 있는 확장성이다. 위 요구사항에서 알 수 있듯이 주요 기능은 그림 3 과 같이 펌웨어와 소프트웨어 수집 및 관리 모듈, 업그레이드 수행 모듈 그리고 업그레이드 정보의 관리 모듈로 구성된다. 설계 내용 중 업그레이드 모듈에서 가장 중요한 부분은 $\mathrm{AMI}$ 환경의 다양한 기기들에 대한 업 그레이드 수행 방법이다. 본 연구에서는 향후 예상되는 1,800 만 고객의 미터 업그레이드를 위하여 펌웨어 업그레이드 서 버와 DCU가 하위 기기에 대한 업그레이드 관리 모듈을 가 지는 구조로 설계하였다. 즉, 펌웨어 업그레이드 서버가 전체 미터의 업그레이드를 수행하기에는 많은 시간과 관리에 한 계가 있으므로, $\mathrm{DCU}$ 가 하위 미터에 대한 업그리이드 수행을 관리하는 구조의 설계이다. 그러므로 그림 4와 같이 DCU는 상위 펌웨어 업그레이드 서버로부터 펌웨어 및 소프트웨어 업그레이드 통제를 받고, DCU에 설치된 에이젼트 프로그램 에 의하여 하위 미터의 펌웨어 및 프로그램의 상태를 모니 터링하고 업그레이드를 수행하는 기능을 갖게 된다.

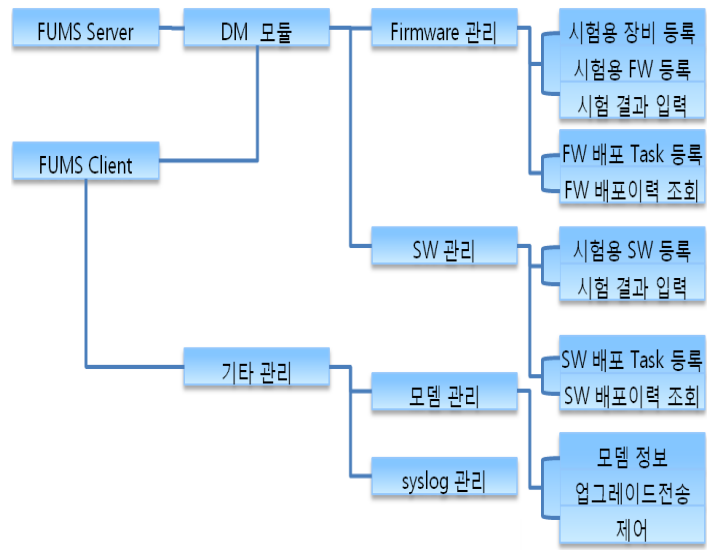

그림 3 FUMS 기능 구성도

Fig. 3 Function configuration of FUMS

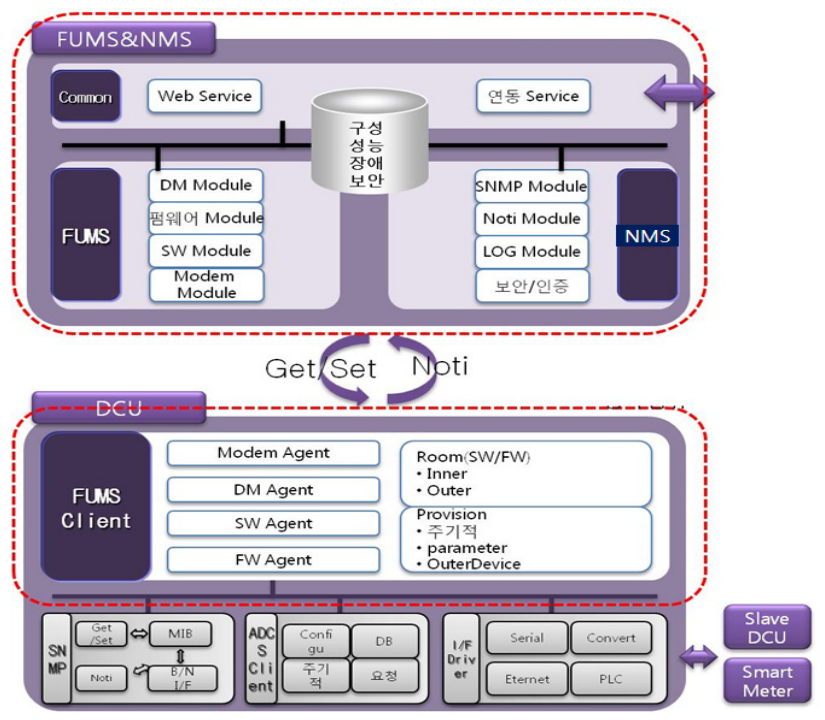

그림 4 FUMS 시스템 구성도

Fig. 4 System configuration of FUMS

소프트웨어 개발을 위한 객체 클래스는 펌웨어 패키지 관 리 클레스와 수행 Task 관리 클래스 그리고 FUMS 에러 및 로그 등을 관리하는 FUMS 이력관리 클래스로 크게 구 성된다. 패키지 관리 클래스는 각 기기 종류별 펌웨어와 $\mathrm{S} / \mathrm{W}$ 의 버전이 관리되고 그 펌웨어 및 $\mathrm{S} / \mathrm{W}$ 의 신뢰성에 대 한 테스트 결과와 실제 파일이 관리 된다. Task 관리 클래 스는 펌웨어 및 $\mathrm{S} / \mathrm{W}$ 업그레이드를 위한 시작시간과 종료시 간이 관리되며 업그레이드가 시행된 장비 소속 정보와 장치 그리고 장비의 상태 등을 관리하게 된다. 마지막 FUMS 이 력관리 클래스는 전체 작업 수행에 대한 시작시간과 종료시 간 작업결과 그리고 설치된 버전정보 등이 관리된다. 또한 개발 프래임웍은 MVC(Model, View, Controller) 패턴을 지 원하는 스트럿처 2(Struts2)와 iBatis 프레임워크 아키텍쳐를 활용함으로써 운영체제에 구애 받지 않고, 안정적으로 시스 템 개발 및 운영이 가능하도록 설계하였다.

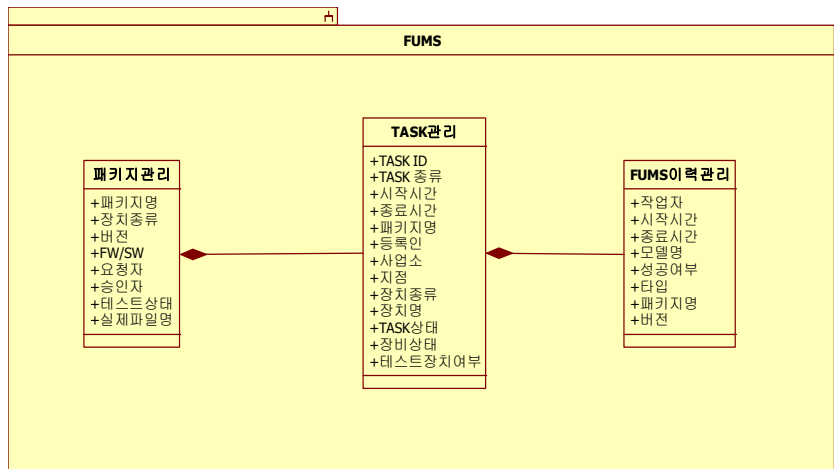

그림 5 FUMS 객체 클래스 구성도

Fig. 5 Object class configuration of FUMS

3.2.2 전력 장비의 자동 등록 관리 프로세스

$\mathrm{AMI}$ 장비의 효율적인 운영을 위해서는 전력 장비의 자동 등록 기능이 필수 요건이다. 즉, 설치할 미터나 $\mathrm{DCU}$ 를 전원 에 연결하면, 자체 부팅 후 자동으로 네트웍 운영센터(NOC) 서버에 접속하여 기기 인증 메시지를 보내며 인증 완료 후 
$\mathrm{NOC}$ 서버는 자동으로 해당 기기 정보를 FUMS 관리 $\mathrm{DB}$ 로 전송하게 된다. 이러한 기기의 자동 인증이 가능하기 위해 서는 그림 6 과 같이 기기 제작업체와 유틸리티간 정보 교환 비즈니스 모델이 정립 되어야 하며, 상호 정보 교환을 위한 데이터 관리 형식과 교환 절차의 표준화 설계가 요구된다. 펌웨어 업그레이드 대상 정보의 FUMS 서버 등록 이후 해 당기기는 관리 대상 장비로 등록되어 $\mathrm{NOC}$ 를 통해 네트웍관 리 및 원격 펌웨어 업그레이드 서비스가 가능하게 된다.

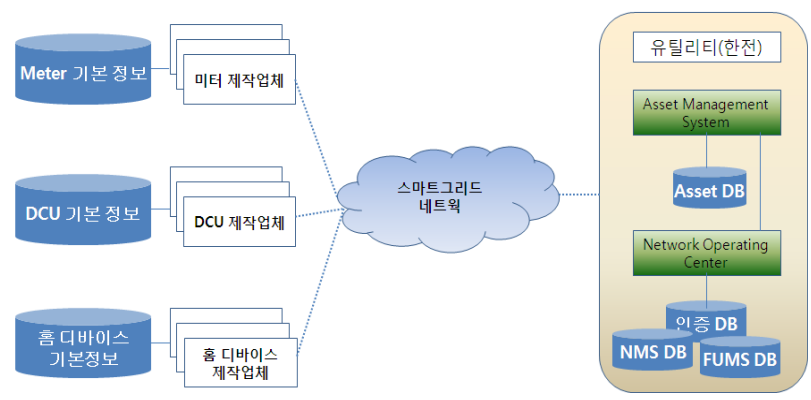

그림 $6 \mathrm{AMI}$ 장비 자동 등록 시스템 체계

Fig. 6 Automatic registration system for AMI device

\subsection{3 펌웨어 업그레이드 프로세스}

그림 7은 원격 펌웨어 대상 장비에 대한 모니터링 및 업 그레이드 방법을 개괄적으로 표현한 순서도로 평상시에는 관리자의 요청시 펌웨어 대상의 기기에 대한 버전 정보를 읽어서 시스템 인터페이스를 통하여 웹 화면으로 표시하고, $\mathrm{DCU}$ 에 대한 펌웨어는 FUMS 서버가 업그레이드를 요청하 여 $\mathrm{DCU}$ 가 업데이트하도록 관리하고, 미터의 펌웨어 업그레 이드는 $\mathrm{DCU}$ 의 FUMS 클라이언트에게 $\mathrm{DCU}$ 하부 미터에 대한 업데이트를 요청하여 DCU의 FUMS 클리이언트가 업 데이트를 시행 후 업데이트 성공 여부에 대한 정보만 FUMS 서버로 넘겨주는 방식의 분산 프로세스를 지향한다.

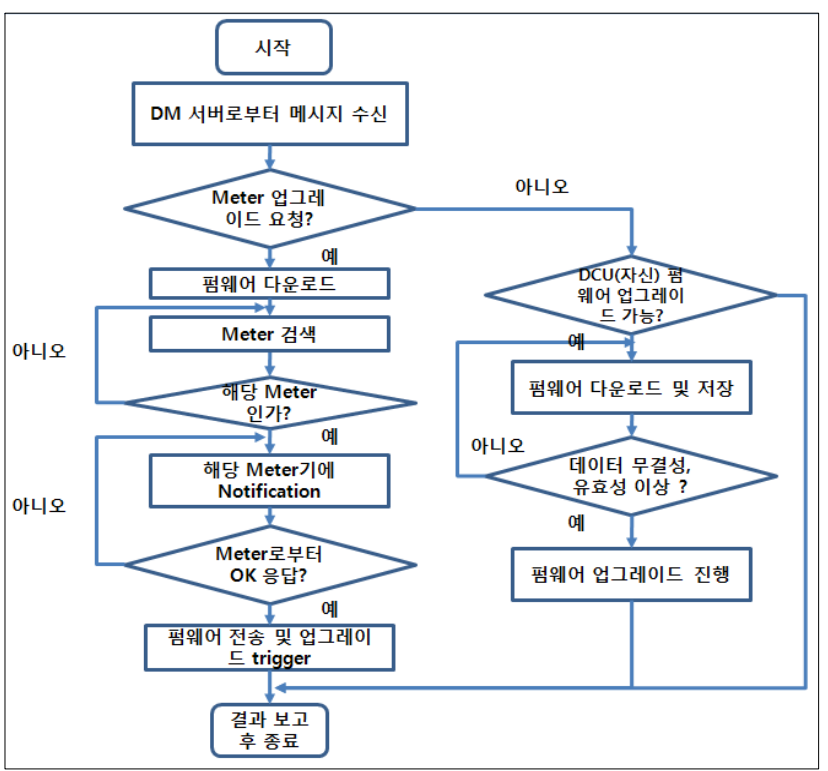

그림 7 FUMS 업그레이드 시퀀스

Fig. 7 Upgrade sequence of FUMS
$\mathrm{DCU}$ 나 미터의 버그 또는 기 설치된 어플리케이션의 수정 및 보완, 신규 서비스 제공을 위한 프로그램 설치가 필요한 경우 FUMS 서버는 단말정보를 확인하여 새로운 버전의 펌 웨어를 배포/설치하게 된다. 이때 $\mathrm{DCU}$ 에 대한 업그레이드 의 경우는 그림 8 과 같이 $\mathrm{FUMS}$ 서버가 $\mathrm{DCU}$ 의 펌웨어 및 소프트웨어 버젼 그리고 상태정보를 직접 모니터링하고 펌 웨어 업그레이드에 대한 프로세스를 직접 제어하게 된다. $\mathrm{DCU}$ 가 아닌 하위단의 미터 업그레이드의 경우는, 서버의 부하를 줄여주기 위한 분산 제어 방식을 이용하게 되는데 이는 $\mathrm{FUMS}$ 서버(DM서버)가 $\mathrm{DCU}$ 에 관리대상 기기에 대한 프로그램과 TASK 수행 정보를 제공하고 FUMS 서버의 일 부 기능(모니터링, 패키지 분할 전송, 중간 결과 확인 등)을 위임하여 최종 업그레이드에 대한 결과만을 보고받는 구조 로 설계하였다(그림 9).
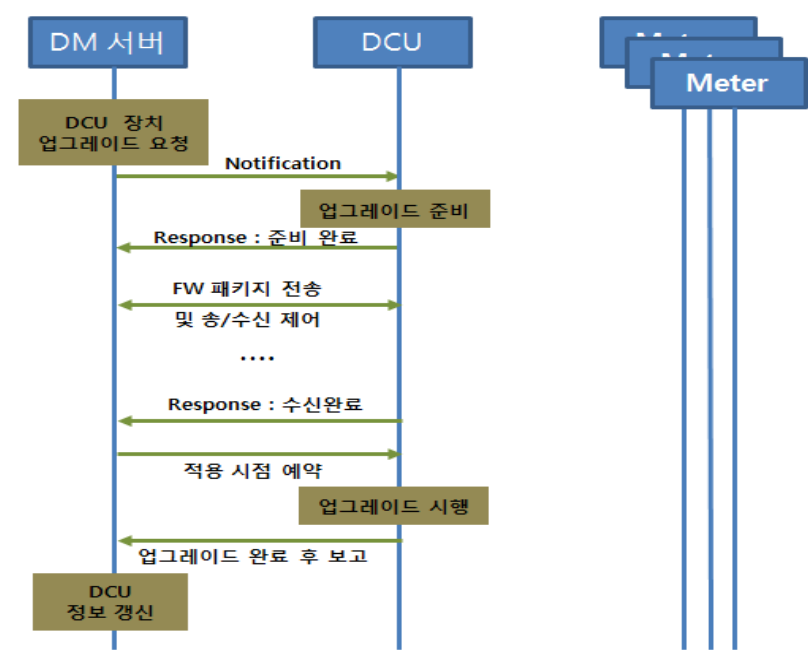

그림 $8 \mathrm{DCU}$ 의 업그레이드 수행 순서도

Fig. 8 Upgrade process diagram of DCU

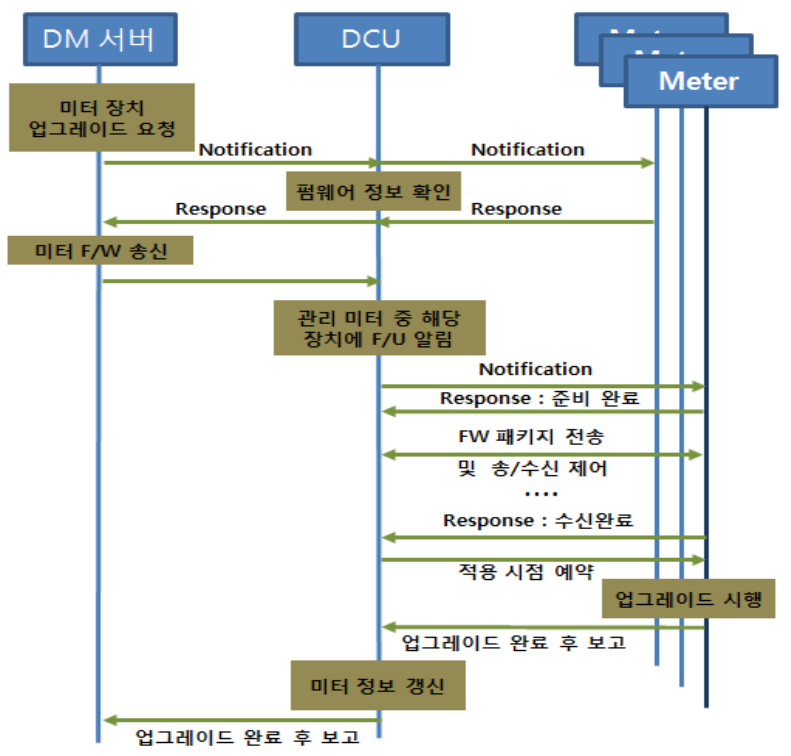

그림 9 미터의 업그레이드 수행 순서도

Fig. 9 Upgrade process diagram of Meter 
그림 8과 그림 9에서 보는바와 같이 펌웨어 업그레이드에 대한 프로세스는 대상 기기 본연의 업무를 진행하면서 또는 본연의 기능에 방해가 되지 않도록 하면서 진행해야하기 때 문에 상세한 설계가 필요하다. 즉, 미터의 경우 펌웨어 업그 레이드를 위해서는 현재 진행중인 미터링 기능을 잠깐 중지 하고 업그레이드를 수행하여야 한다. 미터의 경우 미터링 기능을 중지하기위해서는 미터에 대한 락킹 기능을 상위 FUMS 운영시스템에서 제어하여 락킹 상태를 확인하고 작 업을 수행하여야 한다. 그렇게 함으로써 펌웨어나 운영 소 프크웨어의 업그레이드 기능의 신뢰성을 확보할 수 있으며, 프로그램의 오 작동 현상을 줄일 수 있다. 그리고 미터의 락킹/락킹 해제 등의 프로그램 구현을 위해서는 $\mathrm{AMI}$ 구성 상의 기기들(예, MDMS, $\mathrm{ADCS}, \mathrm{DCU}$, Meter 등) 간의 상 이한 프로토콜을 어떻게 교환하여 어떤 표준을 활용할 것인 가와 같은 프로토콜 측면의 상세한 검토가 필요하다. 본 연 구에서는 MDMS-ADCS-DCU-Meter 구간의 프로토콜 변 환을 위하여 $\mathrm{CIM}$ (Common Information Model), SMCP(Smart Metering concentrator Control Protocol), DLMS와 같은 다양한 프로토콜들의 연결 및 활용 원활히 이루어지도록 프로토콜 변환을 설계하였다. 또한 네트웍의 성능 등을 고려하여 교체하고자 하는 펌웨어 패키지의 분할 전송 단위를 적절하게 설계하여야 한다. PLC 기반의 $\mathrm{DCU}$ 의 경우 미터와의 통신을 위하여 $512 \mathrm{kByte}$ 단위로 전송 프 래임을 설계하였다.

\subsection{4 사용자 인터페이스 설계}

NMS 및 FUMS 서버는 허가된 관리자에 의해서 운영되 며 실제 구현된 운영 시스템은 그림 10 과 같이 전국의 전력 장비를 $\mathrm{DB}$ 로 관리하고 주기적으로 상태 및 성능을 모니터 링 한다. 또 새로운 펌웨어나 소프트웨어가 해당 장비의 공 급자에 의해 릴리즈 될 경우 내부 테스트를 거쳐 배포 일정 을 수립하고 업그레이드를 진행하게 된다. 사용자 역할별 화면 및 세부기능 단위로 접근 권한을 정의하여 관리하고 화면과 기능 접근 시 권한 인증 과정을 거치도록 설계되었 다. 또한 대쉬보드 형태로 사용자 인터페이스 화면을 구성 하여 NMS와 펌웨어 업그레이드 정보를 인터렉티브하게 조 회 할 수 있도록 설계하였다. 그리고 실시간 데이터 정보 를 페이지 리플래쉬 없이 볼 수 있도록 하기위하여 웹페이 지는 Ajax(Asynchronous JavaScript and XML) 기술을 활 용하여 사용자 편의성 및 인터페이스를 최적화 설계하였다.
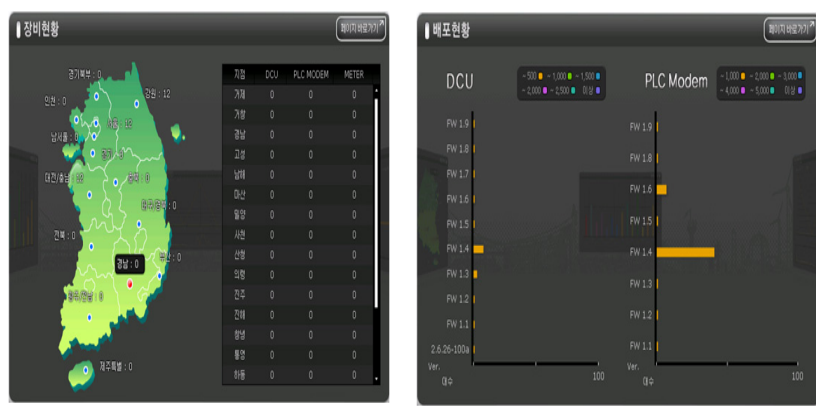

그림 $10 \mathrm{NMS}$ 및 FUMS의 웹 서비스 화면 설계

Fig. 10 Design of web service interface for NMS \& FUMS

\section{4. 결 론}

$\mathrm{AMI}$ 환경에서 펌웨어 업그레이드 기능은 스마트미터의 기본 요구사항 중 하나이며, $\mathrm{AMI}$ 환경의 장비들에 대한 펌 웨어 원격 업그레이드 시스템은 그 기능의 정확성 및 다양 한 장비의 수용성이 요구된다. 원격 펌웨어 업그레이드 시 스템은 일반적으로 펌웨어와 소프트웨어를 대상으로 하며, 시스템의 주기능은 펌웨어와 소프트웨어 수집 및 관리 모듈 과 업그레이드 수행 모듈 그리고 업그레이드 이력의 관리 모듈로 구성된다. 아키텍쳐 측면에서 다수의 다양한 하드웨 어 장비의 업그레이드 수행을 위한 방안으로 분산수행 방식 의 프로세스 구현을 설계하였으며 펌웨어 업그레이드 수행 에 따른 본연의 업무 방해 요소를 제거하고, 부하 분산을 유 도하였다. 원격 펌웨어 업그레이드 시스템의 구현은 인력에 위한 수동적인 $\mathrm{H} / \mathrm{W}$ 장비의 교체 없이 $\mathrm{S} / \mathrm{W}$ 및 펌웨어 교 체만으로 변화되는 환경에 유연하게 대체할 수 있도록 하며 다양한 부가서비스 창출 및 사업화를 지원하게 될 것이다. 또한 유지보수의 비용 측면에서도 큰 장점을 가진다. 향후 미터 하단 홈네트웍의 다양장비에 대한 펌웨에 및 소프트웨 어 업그레이드 요구에도 쉽게 적용이 가능할 것이다. 본 논 문에서 제안한 FUMS 및 $\mathrm{NMS}$ 를 이용한 분산제어방식의 망관리 및 업그레이드 방법을 통해 $\mathrm{AMI}$ 를 성공적으로 구축 할 수 있는 기반 기술을 완성 할 수 있을 것으로 기대된다.

\section{참 고 문 헌}

[1] 한국전력공사, AMI(Advanced Metering Infrastructure) 최종보고서, pp.142-144, 2011

[2] 지식경제부, “스마트그리드 국가 로드맵, pp.26-30, 2010

[3] NIST, "Framework and Roadmap For Smart Grid Interoperability Standards 1.0”, pp. 75-77, 2010

[4] NEMA "NEMA Smart Grid Standards Publication SG-AMI 1-2009 Requirements for Smart Meter Upgradeability ", 2009

[5] 이정준, "AMI의 구조", 정보화 통신, pp. 17-22, 2010

[6] Nam-Joon Jung, A Design of ADCS(Automated Data Collection System) for K-AMI, International Conference on Electrical Engineering, 2010

[7] 김영준, “AMI 환경에서의 전력계량장치 관리 및 원격 업그레이드 방법", 대한전기학회 전기기기 및 에너지 변환시스템 부문회 춘계학술대회 논문집, pp. 233-236, 2011

[8] OMA, Firmware Update Management Object, Open Mobile Alliance Ltd, 2009

[9] EPRI, IEC61559 IntelliGrid Methodology for Developing Requirements for Energy Systems, EPRI, pp. 35-46, 2008 

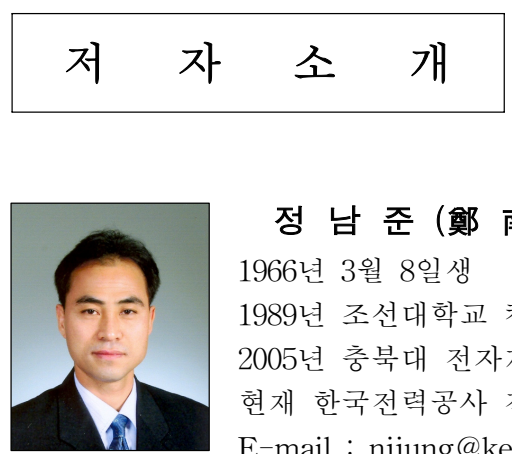

\section{정 남 준 (鄭 南 俊)}

1966년 3월 8일생

1989년 조선대학교 컴퓨터공학과 졸업

2005년 충북대 전자계산학과(석사)

현재 한국전력공사 전력연구원 근무

E-mail : njjung@kepco.co.kr

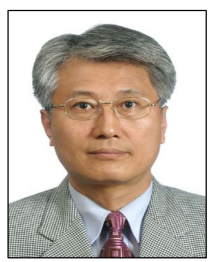

\section{양 일 권 (梁 日 權)}

1954년 4월 24일생

1976년 조선대학교 전기공학과 졸업

1992년 미국 Indiana대 컴퓨터공학과(석

사)

현재 한국전력공사 전력연구원 근무

E-mail : yangilk@kepco.co.kr

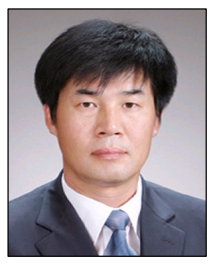

\section{최 승 환 (崔 昇 煥)}

1962년 9월 17일생

1986년 조선대학교 전자공학과 졸업

2004년 충북대 전자계산학과(석사)

현재 한국전력공사 전력연구원 근무

E-mail : captain@kepco.co.kr

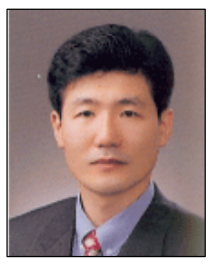

\section{진 영 택 (秦 榮 澤)}

1958년 11월 10일생

1981년 중앙대학교 전자계산학과 졸업

1983년 중앙대학교 전자계산학과(석사)

1992년 중앙대학교 컴퓨터공학과(박사)

현재 한밭대학교 컴퓨터공학과 정교수

E-mail : ytjin@hanbat.ac.kr 